\title{
Synthesis of Transferrin-Mitomycin C Conjugate as a Receptor-Mediated Drug Targeting System
}

\author{
Tetsuro Tanaka, Yoshiharu Kaneo, ${ }^{*}$ and Masahide Miyashita \\ Department of Biopharmaceutics, School of Pharmacy, Fukuyama University, Sanzo, Gakuen-cho, Fukuyama 729-02, \\ Japan. Received October 9, 1995; accepted January 20, 1996
}

\begin{abstract}
Macromolecular conjugates of mitomycin $\mathrm{C}$ (MMC) were synthesized by binding an active ester of glutarylated MMC (MMC-G-OSu) to human holo-transferrin (TF). Water-soluble TF-MMC conjugates (TF-G-MMC) were obtained in a good yield ( $>95 \%$ ) by this method. The MMC content of the conjugate increased $(0.82-9.49 \mathrm{MMC} /$ w\%) with increasing amounts of MMC-G-OSu added to the conjugation mixture. Sodium dodecyl sulfatepolyacrylamide gel electrophoresis (SDS-PAGE) analysis showed no aggregation in these conjugates. ${ }^{125}$ I-TFG-MMC was bound specifically to the TF receptor on Sarcoma 180 cells; the measurement of equilibrium binding of the ${ }^{125} \mathrm{I}$-labeled conjugate resulted in a saturation isotherm. The amount of conjugate specifically bound to the TF receptor decreased as the MMC content of the conjugate increased. However, it was found that the conjugate with an MMC content below $10 \mathrm{~mol} \mathrm{MMC} / \mathrm{mol} \mathrm{TF}$ still retains a binding activity of more than half that of TF. Therefore, when an optimal chemical modification was chosen, TF could be used as a tumor specific drug carrier.
\end{abstract}

Key words tumor targeting; mitomycin C; transferrin; macromolecular conjugate; receptor binding; sarcoma 180

Mitomycin $\mathrm{C}(\mathrm{MMC})$ is an antitumor drug which inhibits the replication of DNA. MMC has severe side effects because it is distributed to normal cells as well as tumor cells. Therefore, a site-specific delivery system to tumor cells is desirable for cancer chemotherapy. A macromolecular carrier system has been developed in an attempt to optimize the delivery of antitumor drugs. Thus far, a variety of effective macromolecular conjugates of MMC has been developed, e.g., antibodies, ${ }^{1,2)}$ dextran, ${ }^{3,4)}$ and poly-[5N-(2-hydroxyethyl)-L-glutamine]. ${ }^{5)}$

Transferrin (TF) is a glycoprotein which transports a ferric ion in the body. ${ }^{6}$ The number of TF receptors on tumor cells is much larger than that on normal cells. ${ }^{7)}$ The targeting of drugs or toxins to tumor cells by a specific drug carrier has long been a topic of interest. ${ }^{4)}$ Since TF is taken up by receptor mediated endocytosis (RME), TF is thought to be one of the useful drug carriers to tumor cells. ${ }^{8-10)}$

We have previously synthesized an albumin conjugate of MMC, which improved the distribution of MMC in tumor tissue. ${ }^{11,12)}$ Furthermore, we have demonstrated that $\mathrm{TF}$ tends to accumulate in the tumor tissue in mice bearing Sarcoma 180 (S180) cells. ${ }^{13)}$ In this study, we have developed a macromolecular conjugate composed of TF and MMC. Since the first step of REM is the binding of $\mathrm{TF}$ to the receptor, we have evaluated the conjugate by examining its binding to the TF receptor on S180 cells.

\section{MATERIALS AND METHODS}

Reagents Human holo TF was obtained from Sigma Chemical Co. (St. Louis, U.S.A.). MMC, glutaric anhydride, $N$-hydroxysuccinimide (HOSu), and $N, N^{\prime}$ dicyclohexylcarbodiimide (DCC) were purchased from Nacalai Tesque, Inc. (Kyoto, Japan). All other chemicals and reagents were of the highest grades commercially available.

Preparation of Transferrin-Mitomycin C Conjugate MMC was covalently attached to $\mathrm{TF}$ through a gluaryl group spacer. An active ester of MMC, $1 \alpha-[4-(N$-suc* To whom correspondence should be addressed. cinimidoxycarbonyl)-butyl]mitomycin C (MMC-G-OSu), was synthesized according to the literature. ${ }^{1)}$ Briefly, glutaric anhydride $(51.3 \mathrm{mg})$ was added to a solution of MMC (50 mg) in dry tetrahydrofuran $(10 \mathrm{ml})$, and the mixture was heated under a nitrogen atmosphere at $60^{\circ} \mathrm{C}$ for $10 \mathrm{~h}$. At the end of the reaction the solvent was evaporated. The residue was dissolved in distilled methanol ( $2 \mathrm{ml}$ ) and was chromatographed on a Sephadex LH-20 column $(2.5 \times 97 \mathrm{~cm})$ developed with distilled methanol. The violet fractions were collected and evaporated to dryness to produce a glutarylated MMC (G-MMC).

G-MMC $(56.0 \mathrm{mg})$ was dissolved in distilled acetonitrile $(3.4 \mathrm{ml})$, and to the solution both HOSu $(21.6 \mathrm{mg})$ and DCC $(155.6 \mathrm{mg})$ were added. The mixture was stirred at $4{ }^{\circ} \mathrm{C}$ under $\mathrm{N}_{2}$ gas for $48 \mathrm{~h}$. Ice-cold water $(7 \mathrm{ml})$ was added to the mixture, which was then filtrated. The filtrate was extracted with distilled chloroform $(10 \mathrm{ml})$ three times. The chloroform layer was evaporated to dryness and yielded crude MMC-G-OSu. It was recrystallized with ethyl acetate-hexane to give a violet powder.

TF $(30 \mathrm{mg})$ was dissolved in $0.1 \mathrm{~m}$ sodium phosphate buffer ( $\mathrm{pH} 7.5$ ) containing $0.1 \mathrm{M}$ sodium chloride $(3 \mathrm{ml})$. To the solution, MMC-G-OSu in $N, N^{\prime}$-dimethylformamide $(0.3 \mathrm{ml})$ was added and stirred at $4{ }^{\circ} \mathrm{C}$ for $16 \mathrm{~h}$. The reacted solution was dialyzed against water at $4{ }^{\circ} \mathrm{C}$. The macromolecular fraction was lyophilized and transferrinmitomycin $\mathrm{C}$ conjugate (TF-G-MMC) was yielded. The MMC content of the conjugate was calculated by the UV absorbance at $363 \mathrm{~nm}$ in the phosphate buffer ( $\mathrm{pH} 7.4)$ with reference to that of the MMC standard.

Sodium Dodecyl Sulfate-Polyacrylamide Gel Electrophoresis (SDS-PAGE) SDS-PAGE of the conjugates was performed according to the method of Laemmli. ${ }^{14)}$

Radiolabeling of Proteins TF or TF-G-MMC $(100 \mu \mathrm{g})$ was labeled with ${ }^{125} \mathrm{I}(1 \mathrm{mCi}$, Amersham Corp., Tokyo, Japan) by the chloramine $\mathrm{T}$ method, ${ }^{15)}$ in which the reaction time was limited to $1 \mathrm{~min}$ to avoid denaturation. Unbound ${ }^{125} \mathrm{I}$ was removed by chromatography on a column of PD-10 (Pharmacia, Uppsala, Sweden).

Tumor Cells S180 cells, kindly supplied by Dr. C.

(C) 1996 Pharmaceutical Society of Japan 
Yamashita (Formulation Research Institute, Otsuka Pharmaceutical Co., Ltd., Tokushima, Japan), were maintained in ddY mice by weekly intraperitoneal transplantation. The tumor cells were collected from the intraperitoneal cavity and were washed twice with ice-cold Eagle's minimum essential medium supplemented with $1 \%$ BSA (BSA/Eagle). In order to wash out the endogenous $\mathrm{TF}$ and to saturate the non-specific protein binding sites, the $\mathrm{S} 180$ cells were incubated in the medium at $37^{\circ} \mathrm{C}$ for $30 \mathrm{~min}$. Then the cells were again washed twice with ice-cold BSA/Eagle before use.

Receptor Binding of TF-G-MMC on S180 Cells S180 cells $\left(5.0 \times 10^{6}\right.$ cells $)$ in $250 \mu \mathrm{l}$ of BSA/Eagle were incubated with ${ }^{125}$ I-labeled ligands $(0.59-116 \mathrm{~nm})$ at $0{ }^{\circ} \mathrm{C}$ for $100 \mathrm{~min}$. To correct nonspecific binding, assays were performed in parallel in the presence of a great excess of unlabeled TF $(60 \mu \mathrm{M})$. After incubation, the cell suspension $(200 \mu \mathrm{l})$ was added to the oil mixture $(150 \mu \mathrm{l}$, olive oil: dibuthyl phthalate $=1: 4$ ) and centrifuged at $5000 \mathrm{rpm}$ for $2 \mathrm{~min}$. A portion of the cell pellet was cut and the radioactivity of bound ${ }^{125} \mathrm{I}$ to $\mathrm{S} 180$ cells was determined with a gamma counter (Aloka 301, Tokyo, Japan).

\section{RESULTS AND DISCUSSION}

We have synthesized G-MMC by the method of Kato et al. ${ }^{1)}$ The coupling of MMC to TF via a glutaryl group was achieved by using MMC-G-OSu to provide covalent amide bonding. The MMC contents of TF-G-MMC are listed in Table 1. The MMC content of the conjugate increased with increasing amounts of MMC-G-OSu added to the reaction mixture. Up to a molar ratio of MMC-G-OSu/TF of 43, approximately half of the MMC-G-OSu added was attached to TF, and the conjugate was obtained in a good yield ( $>95.0 \%$ as protein). Above the molar ratio of 43 , the yield of the conjugate was markedly decreased because of the formation of a water-insoluble product.

The molecular weight of the conjugates was determined by SDS-PAGE (Fig. 1). The electromigration pattern of each TF-G-MMC was identified by a single band, thus $\mathrm{TF}$ did not aggregate to a polymeric form during the conjugation. The molecular weight of the conjugates was increased slightly by the conjugation of MMC (Table 1).

The equilibrium binding of ${ }^{125} \mathrm{I}-\mathrm{TF}$ and ${ }^{125} \mathrm{I}-\mathrm{TF}-\mathrm{G}-$ MMC to $\mathrm{S} 180$ cells at $0{ }^{\circ} \mathrm{C}$ resulted in a saturation isotherm (Fig. 2); the Scatchard's plot of the data gave a non-linear regression line (Fig. 3). Assuming that there are two types

Table 1. Preparation and Characterization of TF-G-MMC

\begin{tabular}{ccccc} 
Conjugate & $\begin{array}{c}\text { Molar ratio of } \\
\text { MMC-G-OSu/TF } \\
(\mathrm{mol} / \mathrm{mol})\end{array}$ & \multicolumn{2}{c}{ MMC content } & $\begin{array}{c}\text { Apparent } \\
\text { molecular } \\
\text { weight }{ }^{a)} \\
(\mathrm{MMC} / \mathrm{w} \%)\end{array}$ \\
\hline 1 & 4.3 & 0.82 & 1.97 & 81 \\
2 & 8.7 & 1.80 & 4.32 & 82 \\
3 & 22 & 4.04 & 9.70 & 83 \\
4 & 43 & 9.49 & 22.8 & 84
\end{tabular}

a) The apparent molecular weight was determined by SDS PAGE of binding sites, $n_{1}$ and $n_{2}$, with association constants $K_{1}$ and $K_{2}$, respectively, the equation becomes:

$$
B=n_{1} K_{1} L /\left(1+K_{1} L\right)+n_{2} K_{2} L /\left(1+K_{2} L\right)
$$

where $B$ and $L$ represent the bound ligand concentration and the free ligand concentration, respectively.On the basis of Eq. 1, a curve fitting was done using the nonlinear least-squares program MULTI. ${ }^{16)}$ Table 2 lists the binding parameters obtained by computer analysis. For highaffinity TF-binding sites, the number $\left(n_{1}\right)$ and the affinity
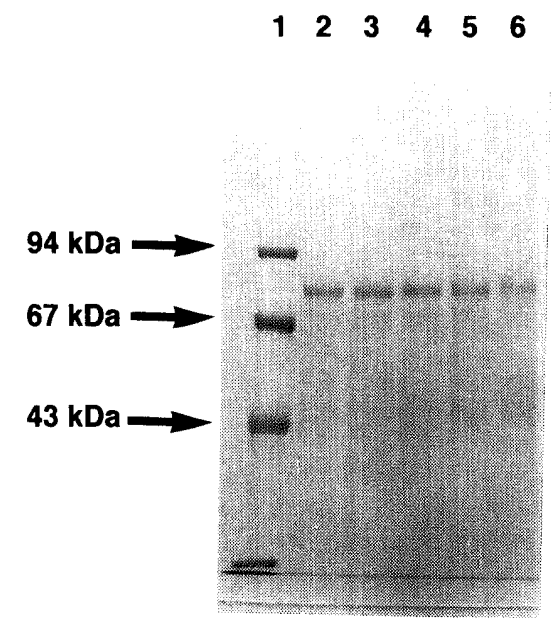

Fig. 1. SDS-PAGE of TF (Lane 2) and TF-G-MMC with Varying MMC Content (Lane 3: 0.82 MMC/w\%, Lane 4: $1.80 \mathrm{MMC} / \mathrm{w} \%$, Lane 5: $4.04 \mathrm{MMC} / \mathrm{w} \%$, Lane 6: $9.49 \mathrm{MMC} / \mathrm{w} \%$ )

Aliquots of the sample were dissolved in the SDS-gel loading buffer containing $5 \%$ of mercaptoethanol, then heat-denatured and loaded on the gel. After electrophoresis, the gel was stained with Coomassie brilliant blue. Lane 1 shows the migration patterns for the standard proteins.
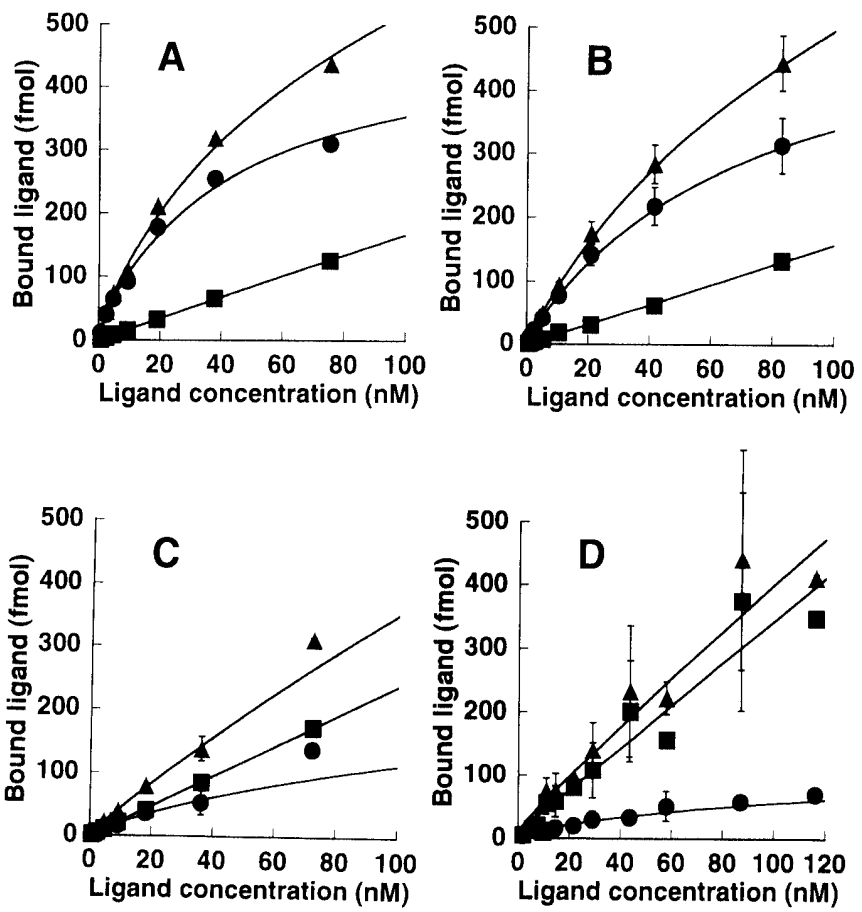

Fig. 2. Binding of ${ }^{125} \mathrm{I}-\mathrm{TF}$ and ${ }^{125} \mathrm{I}-\mathrm{TF}-\mathrm{G}-\mathrm{MMC}$ to $\mathrm{S} 180$ Cells $\left(4.0 \times 10^{6}\right.$ Cells $)$ at $\mathrm{pH} 7.4$ and $0^{\circ} \mathrm{C}$

A, ${ }^{125}$ I-TF; B, ${ }^{125}$ I-TF-G-MMC (0.82 MMC/W\%); C, ${ }^{125}$ I-TF-G-MMC (4.04 $\mathrm{MMC} / \mathrm{w} \%)$; D, ${ }^{225}{ }_{\mathrm{I}-T F-G-M M C}(9.49 \mathrm{MMC} / \mathrm{w} \%)$. Specific binding $(\bullet)$ is the mean of the difference obtained for total $(\boldsymbol{\Lambda})$ and non-specific $(\boldsymbol{\nabla})$ binding. Each line was calculated using the nonlinear least-squares program. MULTI. 

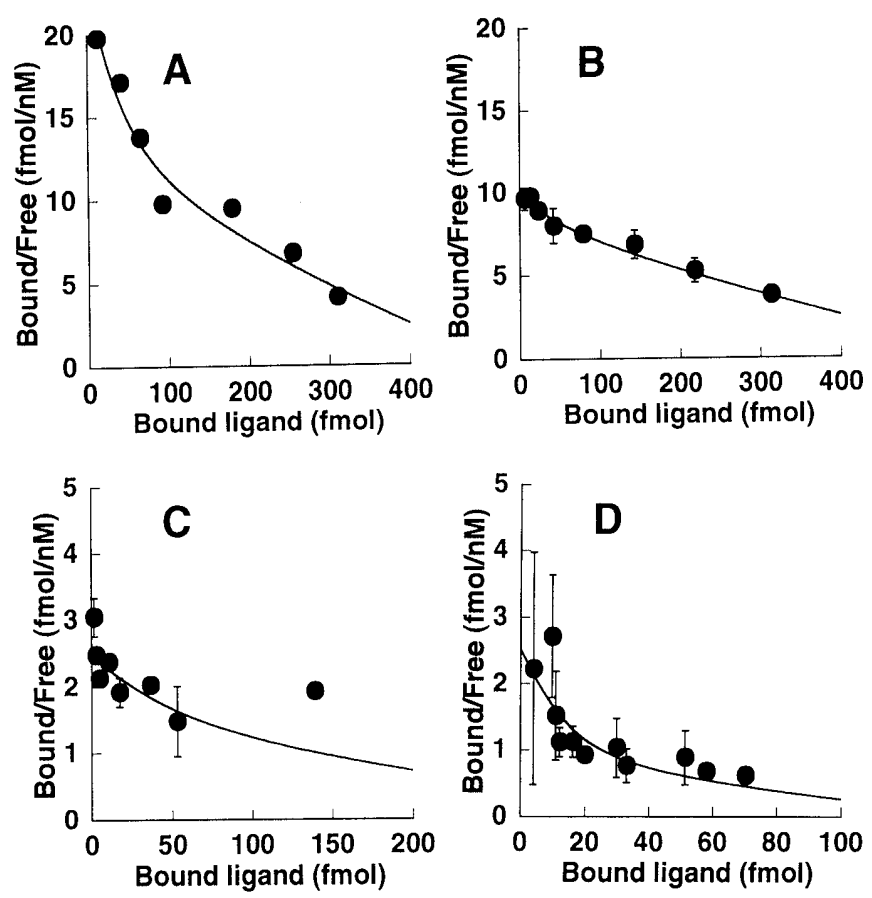

Fig. 3. Scatchard Plot of Specific Binding of ${ }^{125}$ I-TF and ${ }^{125} \mathrm{I}-\mathrm{TF}-\mathrm{G}-$ MMC to S180 Cells $\left(4.0 \times 10^{6}\right.$ Cells $)$ at $\mathrm{pH} 7.4$ and $0^{\circ} \mathrm{C}$

A, ${ }^{125} \mathrm{I}-\mathrm{TF} ; \mathrm{B},{ }^{125} \mathrm{~J}-\mathrm{TF}-\mathrm{G}-\mathrm{MMC}(0.82 \mathrm{MMC} / \mathrm{w} \%) ; \mathrm{C},{ }^{125} \mathrm{I}-\mathrm{TF}-\mathrm{G}-\mathrm{MMC}(4.04$ $\mathrm{MMC} / \mathrm{w} \%) ; \mathrm{D},{ }^{125} \mathrm{I}-\mathrm{TF}-\mathrm{G}-\mathrm{MMC}(9.49 \mathrm{MMC} / \mathrm{w} \%)$.

Table 2. Binding Parameter ${ }^{a)}$ of ${ }^{125} \mathrm{I}-\mathrm{TF}$ and ${ }^{125} \mathrm{I}-\mathrm{TF}-\mathrm{G}-\mathrm{MMC}$ to Sarcoma 180 Cells at $\mathrm{pH} 7.4$ and $0{ }^{\circ} \mathrm{C}$

\begin{tabular}{ccccc}
\hline Compound & ${ }^{125} \mathrm{I}-\mathrm{TF}$ & \multicolumn{3}{c}{$125 \mathrm{I}-\mathrm{TF}-\mathrm{G}-\mathrm{MMC}$} \\
$\mathrm{MMC}$ content & - & 0.820 & 4.04 & 9.49 \\
$(\mathrm{MMC} / \mathrm{w} \%)$ & & & & \\
$n_{1}($ sites $/$ cell $)$ & 4500 & 3600 & 5600 & 2200 \\
$K_{1}\left(\mathrm{M}^{-1}\right)$ & $4.4 \times 10^{8}$ & $1.2 \times 10^{8}$ & $3.7 \times 10^{8}$ & $1.3 \times 10^{8}$ \\
$n_{2}(\text { sites } / \text { cell })_{K_{2}\left(\mathrm{M}^{-1}\right)}^{72000}$ & 86000 & 55000 & 20000 \\
Sum of $n K$ & $2.1 \times 10^{7}$ & $1.2 \times 10^{7}$ & $3.0 \times 10^{6}$ & $4.7 \times 10^{6}$ \\
$\left(\right.$ sites $/$ cell $\left.\cdot \mathrm{M}^{-1}\right)$ & $3.5 \times 10^{12}$ & $1.5 \times 10^{12}$ & $2.2 \times 10^{12}$ & $3.8 \times 10^{11}$ \\
\hline
\end{tabular}

a) Each parameter was calculated using the nonlinear least-squares program, MULTI.

constant $\left(K_{1}\right)$ were 4500 sites/cell and $4.4 \times 10^{8} \mathrm{M}^{-1}$, respectively. For low-affinity TF-binding sites, $n_{2}$ and $K_{2}$ were 72000 sites/cell and $2.1 \times 10^{7} \mathrm{M}^{-1}$, respectively.

The biphasic curve obtained for ${ }^{125} \mathrm{I}-\mathrm{TF}$ was similar to the result of TF-binding analysis of the human adenocarcinoma cell line HT29-D4. ${ }^{17)}$ On the other hand, Klausner et al. ${ }^{18,19)}$ analyzed the binding of TF to human chronic myelogenous leukemia cell line K562 by assuming that the only one type of binding site is available. This discrepancy could be due to the fact that we used a more extensive range of ligand concentration. It has been suggested that the number of TF receptors in various malignant cell lines and cancerous tissues is increased compared with that in normal cells and tissues. ${ }^{7,20)}$ For the sake of comparison with these binding parameters on the various kinds of cells, we used a sum of $n K$ (e.g., $\left.n_{1} K_{1}+n_{2} K_{2}\right)$. The sum of $n K$ of TF on S180 cells, $3.5 \times$ $10^{12}$ sites $/ \mathrm{cell} \cdot \mathrm{M}^{-1}$ was smaller than that on $\mathrm{K} 562(7.2 \times$ $10^{13}$ sites $/$ cell $\left.\cdot \mathrm{M}^{-1}\right),{ }^{18,19)}$ however, it was larger than that on HT29-D4 $\left(1.6 \times 10^{12} \text { sites/cell } \cdot \mathrm{M}^{-1}\right)^{17)}$ and hepatocytes

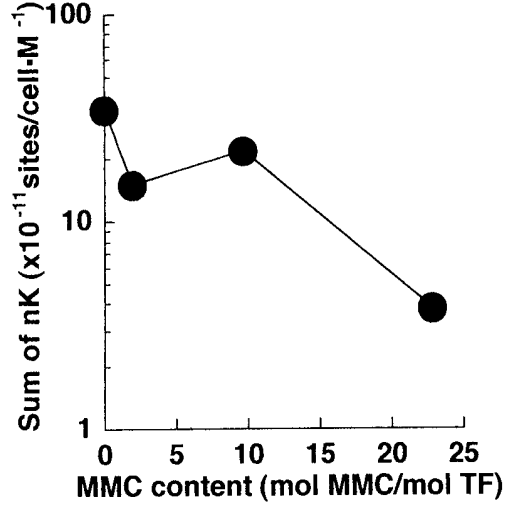

Fig. 4. Effect of MMC Content of TF-G-MMC on the Sum of $n K$ on SI 80 Cells

The binding parameters were obtained by computer analysis.

$\left(5.9 \times 10^{11}\right.$ sites $\left./ \mathrm{cell} \cdot \mathrm{M}^{-1}\right){ }^{21)}$ These results indicated that TF was capable of binding to S180 cells more effectively than to normal cells. The number of total TF-binding sites $\left(n_{1}+n_{2}=76500\right.$ sites/cell $)$ that we found on S180 cells was two-fold larger than that on hepatocytes $(37700$ sites/cell). ${ }^{21)}$ Therefore, TF would be a useful carrier for antitumor drugs to Sarcoma cell lines.

Each equilibrium binding of TF-G-MMC with various MMC content resulted in a saturation isotherm (Fig. 2-B-D). The total binding of the conjugate decreased as the MMC content increased. Nonspecific binding of the conjugate, which was determined in the presence of an excess amount of nonradioactive $\mathrm{TF}$, increased as the MMC content was increased. Consequently, the specific binding of the conjugate to the TF receptor was depressed as the MMC content was increased.

A Scatchard's plot of the specific binding data gave a non-linear regression line (Fig. 3-B-D). The binding parameters of TF-G-MMC for the TF receptor on S180 cells are listed in Table 2 . The numbers of binding sites $\left(n_{1}\right.$ and $\left.n_{2}\right)$ of the conjugate containing 0.82 and 4.04 $\mathrm{MMC} / \mathrm{w} \%$ were nearly equal to those of TF; however, when the MMC content was increased to $9.49 \mathrm{MMC} / \mathrm{w} \%$, $n_{1}$ and $n_{2}$ were decreased to one-half or one-third of those of TF, respectively. The values of $K_{1}$ and $K_{2}$ decreased as the MMC content increased, e.g., TF-G$\mathrm{MMC}$ containing $4.04 \mathrm{MMC} / \mathrm{w} \%(10 \mathrm{~mol} \mathrm{MMC} / \mathrm{mol} \mathrm{TF})$ gave the value of $K_{2}$, which was one-seventh that of TF. These results indicate that the MMC content of the conjugate is an important factor with respect to the binding to the TF receptor.

In order to establish an effective tumor targeting system, we should conjugate MMC as much as possible to the TF molecule without losing the binding activity to the receptor. Figure 4 shows the effect of the MMC content of TF-G-MMC on the sum of $n K$. The value of the sum of $n K$ decreased as the MMC content increased. However, it was found that conjugates with an MMC content below $10 \mathrm{~mol} \mathrm{MMC} / \mathrm{mol} \mathrm{TF}$ still retained more than half the activity of that of TF. Moreover, we examined the binding of TF-G-MMC (1.80 MMC/w\%, $4 \mathrm{~mol} \mathrm{MMC} / \mathrm{mol} \mathrm{TF})$ and its antitumor activity against human leukemia HL60 cells. The conjugate was bound specifically to the $\mathrm{TF}$ receptor on the HL60 cells where the sum of $n K$ was 
$2.0 \times 10^{13}$ sites $/$ cell $\cdot \mathrm{M}^{-1}$, and it exhibited an antitumor activity equivalent to that of MMC (unpublished data).

The binding affinity of TF to its receptor is influenced by ferric ion. At pH 7.2, the sum of $n K$ of diferric TF (holo-transferrin) was $7.2 \times 10^{13}$ and that of apotransferrin was $3.2 \times 10^{12} \cdot{ }^{19)}$ At both the $N$ - and $C$-terminal regions of $\mathrm{TF}$, the ferric ion was directly co-ordinated to two tyrosines, one histidine and one aspartic acid, and was indirectly co-ordinated to an arginine via the bicarbonate anion. ${ }^{22)}$ The primary receptor-binding locus of human TF is thought to be in its $C$-terminal lobe, which contains glucosylated asparagines, ${ }^{23)}$ however, the $N$-terminal lobe enhances the binding of the $C$-terminal lobe. ${ }^{24)}$ In the conjugation method using the active ester of glutarylated MMC, the drug linked randomly to the $\varepsilon$-amino groups of TF via the glutaryl spacer arm, since the 57 lysines are almost uniformly spread in the sequence. ${ }^{23)}$ Therefore, the chemical modification of TF with MMC might promote a conformational change in the TF molecule, then indirectly affect the sites which were recognized by the TF receptor. In conclusion, an optimal chemical modification would make the TF molecule work as a tumor specific drug carrier.

Acknowledgments The authors are grateful to Dr. C. Yamashita of Otsuka Pharmaceutical Co., Ltd. for the gift of S180 cells. The authors are grateful to S. Yamano, N. Kitada, and K. Shibasaki for their technical assistance.

\section{REFERENCES}

1) Kato Y., Tsukada Y., Hara T., Hirai H., J. Appl. Biochem., 5, 313-319 (1983).

2) Noguchi A., Takahashi T., Yamaguchi T., Kitamura K., Takakura Y., Hashida M., Sezaki H., Bioconjugate Chem., 3, 132-137 (1992).
3) Kojima T., Muranishi S., Hashida M., Sezaki H., J. Pharm. Pharmacol., 32, 30-34 (1980).

4) Hashida M., Drug Delivery System, 7, 5-14 (1992).

5) De Marre A., Soyez H., Schachat E., J. Control. Release, 32, 129-137 (1994).

6) De Jong G., Van Dijk J. P., Van Eijk H. G., Clinica Chimica Acta, 190, $1-46(1990)$.

7) Hamilton T., Wada H.G., Sussman H. H., Proc. Natl. Acad. Sci. U.S.A., 76, 6406-6410 (1979).

8) Wagner E., Curiel D., Cotten M., Advanced Drug Delivery Reviews, 14, 113-135 (1994).

9) Berczi A., Ruthner M., Szuts V., Fritzer M., Schweinzer E., Goldenberg H., Eur. J. Biochem., 213, 427-436 (1993).

10) Sasaki K., Kohg Y., Kato J., Kondo H., Niitsu Y., Jpn. J. Cancer Res. (Gann), 84, 191-196 (1993).

11) Kaneo Y., Tanaka T., Iguchi S., Chem. Pharm. Bull., 38, 2614-2616 (1990)

12) Tanaka T., Kaneo Y., Iguchi S., Bioconjugate Chem., 2, 26-269 (1991).

13) Tanaka T., Kaneo Y., Shiramoto S., Iguchi S., Biol. Pharm. Bull., 16, $1270-1275$ (1993).

14) Laemmli U. K., Nature (London), 227, $680-685$ (1970).

15) Greenwood F. C., Hunter W. M., Biochem. J., 89, 114 - 123 (1963).

16) Yamaoka K., Tanigawara Y., Nakagawa T., Uno T., J. Pharmacobio-Dyn., 4, 879-885 (1981).

17) Roiron D., Amouric M., Marvaldi J., Figarella C., Eur. J. Biochem., 186, 367-373 (1989).

18) Klausner R. D., Renswoude J. V., Ashwell G., Kempf C., Schechter A. N., Dean A., Bridges K. R., J. Biol. Chem., 258, 4715-4724 (1983).

19) Klausner R. D., Ashwell G., Renswoude J. V., Harford J. B., Bridges K. R., Proc. Natl. Acad. Sci. U.S.A., 80, 2263-2266 (1983).

20) Niitsu Y., Kohgo Y., Nishisato T., Kondo H., Kato J., Urushizaki Y., Urushizaki I., Tohoku J. Exp. Med., 153, 239-243 (1987).

21) Young S. P., Aisen P., Biochim. Biophys. Acta, 633, 145-153 (1980).

22) Thorstensen K., Romslo I., Biochem. J., 271, 1-10 (1990).

23) MacGillivray R. T. A., Mendez E., Shewale J. G., Sinha S. K., Lineback-Zins J., Brew K., J. Biol. Chem., 258, 3543-3553 (1983).

24) Zak O., Trinder D., Aisen P., J. Biol. Chem., 269, 7110-7114 (1994) 